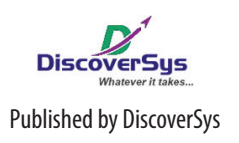

Published by DiscoverSys

\section{The roles of case managers and problems encountered in implementing patient centered care in hospitals}

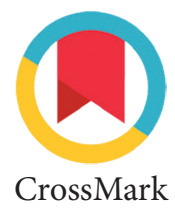

Ni Kadek Yuliati, ${ }^{1 *}$ Ni Made Sri Nopiyani, ${ }^{2}$ Dyah Pradnyaparamita Duarsa ${ }^{2}$

\section{ABSTRACT}

Background and purpose: Patient centered care in hospitals has yet to be well implemented. The role of case managers is very important in the implementation of patient centered care in hospitals. Research publications on the role of case managers in patient centered care in Indonesia remain limited. This study aims to explore the roles of case managers and problems encountered in the implementation of patient centered care in hospitals.

Methods: This study used a qualitative design with a case study approach conducted at Bangli District Hospital in Bali in April 2019. Data was collected through in-depth interviews with seventeen purposively selected informants consisting of ten case managers, one deputy director of medical services, two patient's family members, two specialist doctors and two implementing nurses at Bangli District Hospital. This study uses the Patient Centered Care Framework from Greene which consists of three dimensions in patient centered care namely interpersonal, clinical and structural dimensions. Data was analyzed thematically using deductive and inductive techniques. Data validation was conducted through triangulation of data based on different sources, member checking and peer debriefing.

Results: In this study, five main themes were found regarding the role of case managers in the implementation of patient centered care in hospitals, namely interpersonal, clinical and structural dimensions, support and expectations of case managers. The identified role of the case manager in the interpersonal dimension consisted of listening to patients and families actively, coordination and collaboration in problem solving, providing accurate and easy to understand information about care. Problems encountered included lack of communication between the service provider components and between the service provider with patients and their families. Roles of case manager in the clinical dimension are to hold meetings with a professional team of care givers and continuous monitoring of services to patients, while the issue encountered is the mismatch of time of service provision by specialist doctors. Roles of case managers in the structural dimension is coordination with policy holders, use of information technology and patient reporting. Problems encountered were inappropriate recruitment of case managers, lack of training of case managers, incomplete facilities, inconvenience of services and inadequate incentives. Supports from hospitals for case managers were support of facilities and legality as case managers. Expectations of case managers include case manager training, rewarding and career development opportunities.

Conclusion: The roles of case managers in implementing patient centered care in Bangli District Hospital are not optimal. Efforts to address issues in the interpersonal, clinical and structural dimensions need to be carried out by the hospital management to enhance the role of case managers in the implementation of patient centered care.
'Public Health Postgraduate Program, Faculty of Medicine, Udayana University, ${ }^{2}$ Department of Public Health and Preventive Medicine, Faculty of Medicine, Udayana University

*Correspondence to: Ni Kadek Yuliati, Public Health Postgraduate Program, Faculty of Medicine, Udayana University

kadekyuliati@gmail.com

Keywords: Patient centered care, case manager, interpersonal dimension, clinical dimension, structural dimension Cite This Article: Yuliati, N.K., Nopiyani, N.M.S., Duarsa, D.P. 2019. The roles of case managers and problems encountered in implementing patient centered care in hospitals. Public Health and Preventive Medicine Archive 7(2): 140-147. D01:10.15562/phpma.v7i2.224

\section{INTRODUCTION}

"Patient centered care" refers to health service provision that is friendly and responsive to patients' choices, needs and values, and ensures patients are involved in discussions about their clinical condition. ${ }^{1}$ Health care problems that often occur in hospitals include technology-oriented services (technology centered), doctor-centered, hospital-centered and disease-centered. ${ }^{2}$ One effort that has been developed to create patient centered care is the formation of case managers. Case managers are staff in hospitals that are professional in carrying out patient service management and coordinating with health workers comprehensively so as to provide quality service results. ${ }^{3}$
Bangli Regional Hospital has 41 case managers and has implemented patient centered care since 2014 due to accreditation requirements. The case manager service reporting system currently uses case manager real time (CMRT). A preliminary study conducted at Bangli District Hospital identified several problems related to case management including the difficulty of contacting specialist doctors who treat patients and the uncertainty of doctor's visit time. In addition, recommendations from previous accreditations indicate that filling in a patients' medical records was incomplete and there was a lack of medical personnel who were in accordance with health care standards. These findings 
indicate the suboptimal role of case managers in the application of the concept of patient centered care.

Publications on the role of case managers in the application of patient centered care in Indonesia remain limited and existing publications are mainly in the form of literature review. In addition, most of the studies conducted previously discusses the case manager strategy in conflict management. ${ }^{4-6}$ These studies suggest that case managers can fulfill patient rights through effective communication. This study aims to explore the role of case managers in implementing patient centered care in Bangli District Hospital.

\section{METHODS}

A qualitative study with a case study approach was conducted at Bangli District Hospital from April to May 2019. Data collection was carried out through in-depth interviews with seventeen purposively selected informants, consisting of ten case managers, one deputy director of medical services, two patient's family members, two specialist doctors and two implementing nurses. Case manager informants were recruited based on a number of criteria, namely case managers who had a bachelor nursing degree, had experiences as head of room or deputy head of room for a minimum of three years and had clinical experiences as a care giver of at least three years. Other informants were recruited based on selected criteria, namely the deputy director of medical services as a policy maker, specialist doctors who treat patients in teams and the families of patients who have a history of contact with case managers. In-depth interviews were conducted face-to-face at the agreed location, with a time ranging from 30-60 minutes.

This study refers to the Patient Centered Care Framework from Greene which shows three dimensions in patient centered care namely interpersonal, clinical and structural dimensions. ${ }^{7}$ Semi-structured in-depth interviews were conducted and recorded, and transcripts of the interviews were developed afterwards. Words that are considered important in the transcript were marked, then given a code. Codes that have the same meaning are then grouped and classified into sub-themes for further comprehension to determine the main themes. ${ }^{8}$ Data were analyzed thematically using deductive techniques. ${ }^{9}$ Data analysis was conducted manually. Data was validated through sources triangulation, member checking and peer debriefing. This study has been approved by the Ethics Committee of the Faculty of Medicine, Udayana University/Sanglah General Hospital on March 26, 2019.

\section{RESULTS}

\section{Characteristics of informants}

Table 1 shows the characteristics of the informants consisting of the deputy director of medical services, specialist doctors, case managers, implementing nurses and patients' families. The age of the informants is in the range of 33-51 years. Based on the level of education, the highest education of the informants is masters and the lowest is high school. The informants have worked in the range of 5-30 years.

Our study shows five main themes regarding the roles of case managers in the implementation of patient centered care in Bangli District Hospital, consisted of the roles in the interpersonal, clinical and structural dimensions, hospital support for case managers and the expectations of case managers in carrying out their role in implementing patient centered care. A summary of the themes and sub-themes from the results of the in-depth interviews is presented in Table 2.

\section{Case managers in the interpersonal dimension of patient centered care}

One of the case manager's roles in the interpersonal dimension identified in this study was to listen to patients and families actively. Active listening to the feelings of patients and families is conducted by trying to understand and find solutions to the problems experienced by patients and families, as stated by the following informants.

"We have to listen to the patient and family complaints. In addition we must also explain and care more for patients, listen to all complaints of patients and their families. And help solve problems faced by patients and we are still bridging to communicate" (CM-03)

Another role that case managers play in the interpersonal dimension is coordination and collaboration in problem solving. Coordination is carried out by case managers in the form of teamwork or collaboration with all professional caregivers. Coordination with all professional caregivers is considered important to be able to provide good service so that it can provide satisfaction to patients or patients' families, as mentioned by the informants below.

"Yes, as explained before you need to work with the patient. So in terms of collaboration, if there is a patient need that is not met, for example, and requires coordination and collaboration with the hospital, of course, our role as case manager involes coordinating this" (CM-01) 
Table 1 Characteristics of informants

\begin{tabular}{lccllc}
\hline Informant Code & Age & Gender & Education & Position & Working period (years) \\
\hline WD-01 & 47 & Male & Masters & Ward director & 24 \\
DR-01 & 37 & Male & Specialist & Specialist doctor & 11 \\
DR-02 & 43 & Female & Specialist & Specialist doctor & 5 \\
CM-01 & 42 & Male & Nurse & Case manager & 23 \\
CM-02 & 47 & Female & Nurse & Case manager & 26 \\
CM-03 & 37 & Female & Undergraduate & Case manager & 19 \\
CM-04 & 41 & Male & Nurse & Case manager & 15 \\
CM-05 & 36 & Female & Nurse & Case manager & 9 \\
CM-06 & 37 & Female & Nurse & Case manager & 15 \\
CM-07 & 42 & Female & Nurse & Case manager & 20 \\
CM-08 & 51 & Female & Undergraduate & Case manager & 30 \\
CM-09 & 40 & Female & Nurse & Case manager & 13 \\
CM-10 & 38 & Female & Nurse & Case manager & 15 \\
N-01 & 33 & Female & Diploma & Nurse & 10 \\
N-02 & 35 & Female & Diploma & Nurse & 15 \\
PF-01 & 45 & Female & High school & Patient's family & NA \\
PF-02 & 36 & Female & High school & Patient's family & NA \\
\hline
\end{tabular}

Informant codes: $\mathrm{WD}=$ ward director, $\mathrm{SD}=$ specialist doctor, $\mathrm{CM}=$ case manager, $\mathrm{N}=$ nurse, $\mathrm{PF}=$ patient's family.

\section{Table 2 Summary of the results of the in-depth interviews}

\begin{tabular}{|c|c|}
\hline Theme & Sub theme \\
\hline $\begin{array}{l}\text { Role in the interpersonal } \\
\text { dimension }\end{array}$ & $\begin{array}{l}\text { The role of case managers: actively listening to patients and families, coordination } \\
\text { and collaboration in problem solving, providing accurate and easy to understand } \\
\text { information about care. } \\
\text { Problems: lack of communication between service providers, lack of } \\
\text { communication between patient and family service providers. }\end{array}$ \\
\hline Role in clinical dimensions & $\begin{array}{l}\text { The role of case managers: hold meetings with professional caregivers, monitor } \\
\text { patient services on an ongoing basis. } \\
\text { Problem: Incompatibility of service delivery time by specialist doctors }\end{array}$ \\
\hline $\begin{array}{l}\text { Role in structural } \\
\text { dimensions }\end{array}$ & $\begin{array}{l}\text { The role of case managers: coordination with policy holders, use of information } \\
\text { technology and patient reporting. } \\
\text { Problems: inadequate case manager recruitment, lack of training of case managers, } \\
\text { incomplete health service facilities, service inconveniences, inadequate incentives. }\end{array}$ \\
\hline Hospital support & There is legality as a case manager, there is support for the case manager. \\
\hline $\begin{array}{l}\text { Expectations of case } \\
\text { manager }\end{array}$ & Case manager training, rewarding, career development opportunities. \\
\hline
\end{tabular}

"As explained earlier, we need to collaborate with other professional caregivers team. We continue to collaborate in relation to planning, infrastructure and other aspects of service provision as well. We must also coordinate effectively horizontally and vertically including coordination with specialists" (CM-02)

Providing accurate and easy to understand information about patient care is also one of the case manager roles at the interpersonal dimension. The case manager's role is to provide detailed information to the patient or patient's family if there are problems they are experiencing. Whatever action is taken against the patient, a case manager must communicate using language that is easily understood by the patient and accompany the patient's family so that later the patient's needs are met, as shown in the following informant's quote.

"As I said we as case managers keep providing information to patients or their families if there is something not understood by patients and we are trying to meet their needs" (CM-07) 
"Whatever we do, whatever actions we do, we keep communicating and supporting the family, for example explaining in a language that is easy to understand. Usually when explaining to ordinary people who don't know about health, they just have to use language that is simple and easy to understand by the patient and the patient's own family" (CM-09)

This study shows that the problem encountered in the interpersonal dimension is the lack of communication between service provider components in the service delivery carried out by several professional groups such as specialist doctors, nurses and case managers. Some informants said that it was difficult to contact a specialist on a holiday and were reluctant to contact a specialist on a holiday for fear of disrupting their time with their families. These statements are in accordance with the quotation below.

"Yeah ... hmhmhm ... I think the problem is the lack of communication. We have difficulty contacting a doctor when on holidays if a patient complains if we complain we have difficulty communicating with the specialist doctor, for example, such as when there was a problem patient that day, the patient complained of pain and then the nurse contacted the specialist doctor but could not, coincidentally at that time I was on duty the case manger...we could not get in touch with the patient's doctor so I reported it directly to the vice president and reported to the emergency room doctor so that the patient was given emergency assistance" (CM-07)

"Now that's it, right sometimes we report the patient to the doctor but the doctor is hard to contact, I, as a nurse, also sometimes feel reluctant to contact the specialist doctor especially during holidays because it's the holidays maybe when the doctor is with his family so I sometimes I was afraid to contact, then I reported it to the case manager and the case manager immediately helped us to contact the doctor" (PN-01)

Constraints on communication between the health service provider teams occur because communication is not fully running well and there is no commitment in the team in terms of building a good communication. Effective communication within the healthcare provider team is an important requirement in providing patient centered care. ${ }^{4,10}$ A study conducted in Magelang, Central Java, on the description of doctor and nurse communication reported communication barriers between doctors and nurses occur largely due to unsupportive work environment factors.

Another problem found in the interpersonal dimension is the lack of communication between the specialist doctor, the patient and the patient's family, which is caused by language constraints in the delivery of information and commitment to time. It is said that doctors often use medically scientific language that is difficult for patients to understand, and seem to rush an examination every time so that there is no two-way communication between the doctor and the patient and his family. This was stated by the informant as in the following quote.

"Yes the problem is communication, for example between doctors. The doctor explains an illness, usually the doctor must provide information to the patient, for example explaining in language that is easy to understand. Usually when explaining to ordinary people who don't know about health, they just have to use language that is simple and easy to understand by the patient and the patient's own family"(CM-09)

"Regarding consultations with the doctor it is something like this... because I asked them about my mother's illness, the doctor gave me information, but sometimes I was not satisfied with the information. There were doctors who used medical language so I didn't understand what they were talking about. The doctor was always in a rush too"(PF-01).

\section{The role of case managers in the clinical dimension of patient centered care}

The role of case managers in the clinical dimension is to hold meetings with professional caregivers. To expedite the role of case managers, activities are needed that can strengthen and evaluate their performance, namely through regular meetings with all professional caregivers and case managers aimed at making the best decisions for patient recovery. This was affirmed by the informant as in the quote below.

"Usually we have meetings, a regular meeting, coordinated every 2nd and 4th week. So every 2nd and 4th there is coordination, which usually involves management, there is a case manager and all of what is called a medical committee. In these meetings we discuss issues related to patients, facilities, all get immediate direct follow-up at the time"(CM-02)

"So we do regular monthly meetings, what are the obstacles and what kind of solutions the future 
holds. We have a routine meeting and we also try to coordinate meetings every morning and afternoon before going home to find out the problems that happened that day so we can immediately find a solution"(WD-01)

In addition to holding regular meetings with professional caregivers, case managers carry out continuous monitoring of patient services. Case managers are generally responsible for ongoing coordination between health service providers and patient care throughout the hospital stay. Continuity of monitoring services to patients is done to determine the problems that occur in the service. Below is a quote that supports this statement.

"Eee, we carry out a total of 24 hours of service, especially on holidays, there are afternoon shifts, night shifts and in holidays there are morning shifts. The case managers conduct monitoring. When there are problems the case manager reports back" (WD-01)

"We carry out continuous monitoring related to the service provided to the patient, assessing the service provided from the time of admission to the time when they leave" (CM-02)

Problems encountered in the clinical dimension are continuity and accessibility of medical services provided by specialist doctors, lack of timeliness of visits and absence of doctors coming to examine patients during holidays. These problems have an impact on patients or families who question the doctor's schedule visit, patients must wait for the arrival of doctors and find it difficult to meet with doctors who treat patients. This shows that the doctor's visit had not been carried out in accordance with standards, as stated by the following informants.

"If there are problems with implementation, there may be some obstacles. One of them is about visiting doctors, doctors come to see patients not on time sometimes in the morning, sometimes in the afternoon and sometimes in the evening so the patient's family must wait for the doctor's arrival, perhaps the obstacle of the doctor is surgery or something else" (CM-05)

"It's just a bit difficult to find a doctor, it was a bit difficult to meet the doctor, they would always come at different times. Then sometimes if there is a complaint about my father, I want to ask the doctor. But he is nowhere to be found" (KP-02)
The findings of our study are consistent with a study conducted in Kediri City, East Java Province, which shows that the delay in the arrival of doctors in providing services affects patient satisfaction in hospital outpatient wards. If doctors arrive late to provide services, patient satisfaction will decrease and vice versa if doctors arrive on time, patient satisfaction will increase.

\section{Case managers in the structural dimension of patient centered care}

The role of case managers within the structural dimension is coordinating with policy holders. Problems faced by service providers must immediately be solved and in this case a case manager cannot be alone in making decisions, as stated by the following informants.

"Every time we have a problem, we coordinate and report it directly to the supervisor. If there is a problem in the service department, we report it to the service representative. If there is a financial problem, we will go to the general finance section. At each level of service provision we have a supervisor to report to. If we cannot contact the vice director, we go directly to the director" (CM-03)

This finding is consistent with a study in Semarang which found that case managers need to collaborate to provide health services to patients effectively and efficiently. ${ }^{6}$ Case managers play an active role as a liaison between patients with doctors or other health workers needed in obtaining care. ${ }^{6}$

Case managers also use information technology in reporting patient problems that require immediate decision making, as stated by the case manager informant below.

"In the reporting there are manuals and some are online. If there is a manual there is a form which we fill in: there is patient data, there is the amount of bed capacity, how many beds are occupied and how many are not. If the problem is set forth in the form of the WA group, we have the WA group. In the form of CMRT, the charging system is entered via online CMRT so that when there is a problem we enter it in the CMRT data. There is already there. If the problem is related to the facility, we will go to the supporting vice president. So we can put all of it through the CMRT, and all the problems can be handled directly through the CMRT"(CM-02)

These findings are in line with a study conducted in Semarang, which revealed that risk management reporting by the Quality Committee uses 
the hospital's internet network media, IT-Blog. ${ }^{14}$ In addition, communication is also carried out using telephone, Whatsapp groups, or by meeting in person, so that all stakeholders can receive the same information.

The problem found in the structural dimension is the recruitment of case managers who do not meet the established criteria including limited working experience and the lack of clarity about the functions and tasks of the case manager. This was stated by the following informant.

"Recruitment for case managers is inadequate, and I don't understand why I was also chosen as a case manager, because I also haven't received case manager training" (CM-04)

"The recruitment of case managers must be in accordance with existing criteria, not only in terms of length of service, but also in education... yeah ... the case manager is neither given training, for example, at least training in communication etc so that later we can actually carry out our tasks not just hide in the shadow of the doctor hehehehe"(CM-07)

Another problem that is also found in the structural dimension is the lack of training for a case manager. Lack of training given to case managers will prevent a case manager from carrying out his role. The informant stated that he had not yet received training and needed to get training in accordance with applicable standards.

"So far there has been no training for the case manager... just given brief introductions. So we are fumbling with what we are learning by ourselves, we have to find out information via our own googling-like, really is that a case manager?" (CM-03)

"There is no training for case managers in Bali,... you can train elsewhere, but you might not have a budget yet" (CM-08)

The problem of incomplete health care facilities in hospitals was also found in this study, where the lack of available facilities would hamper service activities and patient comfort, as stated by the following informant.

"There is no routine maintenance of tools and equipment, and for facilities and infrastructure in patient rooms in class 3 there are no air conditioners no fans either, so patients often get hot"(CM-02)
"We are still lacking facilities so far, so far the problem is for CT scan patients. Yes, here we have CT scan. But it only works for scanning a patient's head" (CM-03)

The patient $>$ family informant revealed the problem of discomfort when visiting the hospital because of the high number of visitors with unruly visiting hours and the lack of a clean toilet in the room so it often gave off an unpleasant odor. The following is the quote from the informant.

"Yes, the visitors are very busy, the visiting hours are vague and the toilet in the room is filthy, sometimes it smells of urine because there are patients who do not flush after going to the toilet so the room smells" (KP-01)

A study at a hospital in North Kalimantan on the comfort of patient care at the hospital showed that the cleanliness of the room at the hospital was quite well maintained, only there were no trash bins in the room or in the bathroom. Furthermore the available bathroom does not provide facilities for patients who experience physical disability. ${ }^{13}$

Another problem found in the structural dimension is inadequate incentives. The informant stated that he had received an incentive but felt it was still lacking because it was incompatible with his workload as a case manager. The following are excerpts from informants stating this.

"If there is an incentive during the distribution of workload, we get points, plus additional points as a case manager, even though the points are not worth it to be honest. But there is something that distinguishes us as case managers from ordinary staff because the role of case managers is quite heavy and involves all hospital services. So it really should be improved. Not based on points, but based on percentage. Because different points are the same based on percentages. The point value is 10 , right, the percentage can be 100"(CM-02)

"There is an incentive for it, but it's still not in line with what we do as a case manager" (CM-09)

\section{Hospital support for case managers in achieving patient centered care}

One of the supports from hospitals given to case managers is the legality of their role as case managers as outlined in a decree, as the following informant explained.

"There is a director's decree for the case manager" (WD-01) 
"There is a decree on the formation of a case manager, a decree that outlines that to become a case manager one is chosen perhaps from work experience, more than 10 years, for example" (CM-02)

Facility support in the form of a special workspace and mobile phones as communication media has also been provided to the case manager. The hospital has tried to provide the facilities needed by a case manager to assist the patient-focused service process, as the following informant statement.

"Facilities for work spaces are combined with admissions in front of special rooms. If you want internal communication, you can use internet telephones, but for outgoing communication alternately use a special mobile phone" (WD-01)

"Facilities provided by the hospital to us are case managers in the form of cellphones and passwords to enter the CMRT online system" (CM-09)

\section{Case manager expectations in achieving patient centered care}

Interviews with case manager informants showed that they expect training for case managers so that the function of case managers can run effectively and efficiently and the quality of services provided can be more optimal, as the case manager informants said below.

"In the future, I would like to see more training, synergistic training in accordance with the SOP and on our role as a case manager"(CM-01)

"My hope is that I will be given training, communication training, what is discharge planning, so I know about the main task of a case manager" (CM-03)

An important basic training given to a case manager is training related to the implementation of patient centered care. Patient centered care is an important component in providing quality health services and this concept is recommended for inclusion in service provider training by RS.15 Accreditation Standards.

This study also shows that giving rewards in the form of financial incentives and career development opportunities is also expected by case manager informants. Insufficient rewards greatly affect one's motivation to work and career development in the hope that case managers want in addition to material rewards, because career advancement is an appreciation for the work done by someone. Following are excerpts from interviews that state this.

"I hope that incentives will be given in the form of additional money to be more motivated to work" (CM-07)

"Well ... I hope for career advancement as well in the future, to be rewarded as case managers (CM-05)

A study in Jombang shows that implementing nurses who had high career expectations tended to have low work performance. Therefore the hospital management is recommended to plan and develop the career of individuals and organizations to improve the work performance of implementing nurses. ${ }^{16}$

\section{CONCLUSION}

The roles of case managers in achieving patient centered care in Bangli District Hospital remain not optimal as there are issues in the interpersonal, clinical and structural dimensions. Problems in the interpersonal dimension consist of lack of communication between components of the service provider and between the service provider with patients and families. Problems in the clinical dimension consist of the lack of continuity and accessibility of medical services provided by specialist doctors. Problems in the structural dimension consist of inappropriate case manager recruitment, lack of case manager training, incomplete facilities, inconvenient services and inadequate incentives. Therefore, efforts to improve all problems in all three dimensions need to be done by the management of Bangli District Hospital to increase the role of case managers in implementing patient centered care.

\section{ACKNOWLEDGEMENTS}

The authors would like to thank the Director of Bangli District Hospital for giving permission and facilitating this study. Thanks also go to the informants and all those who have helped the data collection for this study.

\section{REFERENCES}

1. Institute of Medicine. Crossing the quality chasm: A new health system for the 21st century. Washington DC: National Academy Press; 2001.

2. Hospital Accreditation Committe. Standar akreditasi rumah sakit [Hospital accreditation standards]. Jakarta: Hospital Accreditation Committe; 2012. 
3. Hospital Accreditation Committe. Panduan Praktik Manajer Pelayanan Pasien (Guidelines for practicing patients services manager]. $1^{\text {st }}$ edition. Jakarta: Hospital Accreditation Committe; 2016.

4. Aeni WN. Pengembangan case manager dalam patient centered care [Case manager development in patient centered care]. Jurnal Manajemen Keperawatan. 2014;2(2):126-43.

5. Noviasari, Kamil H. Pelaksanaan standar case management oleh case manager di RSUD dr. Zainoel Abidin Banda Aceh [The implementation of standard case management by case manager at the dr. Zainoel Abidin Hospital, Banda Aceh]. Jurnal Ilmiah Mahasiswa Fakultas Keperawatan. 2017;2(2):1-5

6. Kustriyani M. Pelaksanaan manajemen konflik interdisiplin oleh case manager di ruang rawat inap RSUD Tugurejo Semarang (Tesis) [The implementation of interdiscipline conflict management by case manager in inpatient ward Tugurejo Hospital, Semarang (Thesis)]. Semarang: Diponegoro University; 2016.

7. Greene SM, Tuzzio L, Cherkin D. A framework for making patient-centered care front and center. The Permanente Journal. 2012;16(3):49-53.

8. Creswell JW, Poth CN. Qualitative inquiry and research design: Choosing among five approaches. SAGE Publishing; 2007.

9. Bungin B. Analisis data penelitian kualitatif [Qualitative research data analysis]. Jakarta: Raja Grafindo Persada; 2012.

10. Arianto. Komunikasi kesehatan (Komunikasi antara dokter dan pasien) [Health communication (communication between doctor and patient)]. 2013;1-13.

11. Setyawati A, Winarso MS, Palupi NWN. Gambaran komunikasi dokter dan perawat sebagai salah satu aspek kolaborasi [Communication between doctors and nurses as an aspect of collaboration]. Jurnal Ilmu Keperawatan. 2009;4(1):63-67.
12. David, Hariyanti T, Widayanti EL. Hubungan keterlambatan kedatangan dokter terhadap kepuasan pasien di instalasi rawat jalan [The association between the late doctor visit and patient satisfaction at the outpatient ward]. Jurnal Kedokteran Brawijaya. 2014;28(1):31-35.

13. Amir H. Analisis kualitas pelayanan rawat inap di Rumah Sakit Umum Daerah Kb. Nunukan Kalimantan Utara periode BPJS tahun 2016 (Tesis) [Analysis of inpatient services quality at Nunukan District Hospital, North Kalimantan during the period of 2016 national health insurance (Thesis)]. Universitas Terbuka; 2016.

14. Yulianingtyas R, Wigati PA, Suparwati A. Analisis pelaksanaan manajemen risiko di Rumah Sakit Islam Sultan Agung Semarang [Analysis of the risk management implementation at the Sultan Agung Moslem Hospital, Semarang]. Jurnal Kesehatan Masyarakat. 2016;4(4).121-128.

15. Hospital Accreditation Committe. Standar nasional akreditasi rumah sakit [Hospital accreditation national standards]. $1^{\text {st }}$ edition. Jakarta: Hospital Accreditation Committe; 2012

16. Zakaria A. Analisis hubungan harapan karir perawat pelaksana dengan prestasi kerja di RSUD Swadana Jombang [Analysis of the association between job expectation and work achievement at the Swadana Hospital, Jombang]. Jurnal EduHealth. 2010;1(1):79-94.

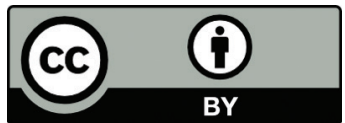

This work is licensed under a Creative Commons Attribution 